\title{
Three Records of Rare Blue American Bullfrogs, Lithobates catesbeianus, in Nova Scotia, Canada
}

\author{
JoHn GILHEN ${ }^{1,3}$ and RonALd W. RUSSELL ${ }^{2}$ \\ ${ }^{1}$ Nova Scotia Museum of Natural History, 1747 Summer Street, Halifax, Nova Scotia B3H 3A6 Canada \\ ${ }^{2}$ Department of Biology, Saint Mary’s University, 923 Robie Street, Halifax, Nova Scotia B3H 3C3 Canada \\ ${ }^{3}$ Corresponding author: gilhenja@gov.ns.ca
}

Gilhen, John, and Ronald W. Russell. 2015. Three records of rare blue American Bullfrogs, Lithobates catesbeianus, in Nova Scotia, Canada. Canadian Field-Naturalist. 129(4): 395-398.

We report three records of a rare blue American Bullfrog, Lithobates catesbeianus, from Nova Scotia, Canada.

Key Words: Blue bullfrog; American Bullfrog; Lithobates catesbeianus; dermal pigmentation; amphibian; Nova Scotia

Dermal pigmentation in amphibians is determined by chromatophores, of which the major ones are melanophores, xanthophores, and iridophores. Colouration in adult amphibians is controlled by the dermal chromatophore unit (DCU), which is formed during metamorphosis (Yasutomi and Yamada 1998). A DCU consists of xanthophores located uppermost in the dermal layer, melanophores at the bottom, and iridophores between (Bagnara et al. 1968). Xanthophores contain yellow pigments, melanophores express black or brown pigments derived from melanin, and iridophores contain iridescent or reflective pigments. Iridophores reflect and scatter the light that falls on them to produce a blue colour; however, the reflected light passing through the yellow xanthophores in the upper DCU appears green to the human eye. This is the basis of the usual green skin colour in adult frogs. When yellow pigment in the uppermost xanthophore layer of the DCU is sparse or absent, the frog will appear blue (axanthic). Blue colouration is highly variable and can be subtle in individual frogs.

Blue colour patterns are rare in amphibians, although they tend to be more common in Ranidae relative to other anuran families (Jablonski et al. 2014). A few cases of blue American Bullfrogs, Lithobates catesbeianus, have been documented (Berns and Uhler 1966; Bagnara et al. 1978; Bechtel 1995; Dodd 2013); however, location details associated with these observations are lacking. Reports of blue bullfrogs are rare in Nova Scotia. In over 50 years of amphibian observations in this province, we have recorded only three individuals, from widely separate localities on the mainland of Nova Scotia (Figure 1). There is some variation in the colour pattern of the three.

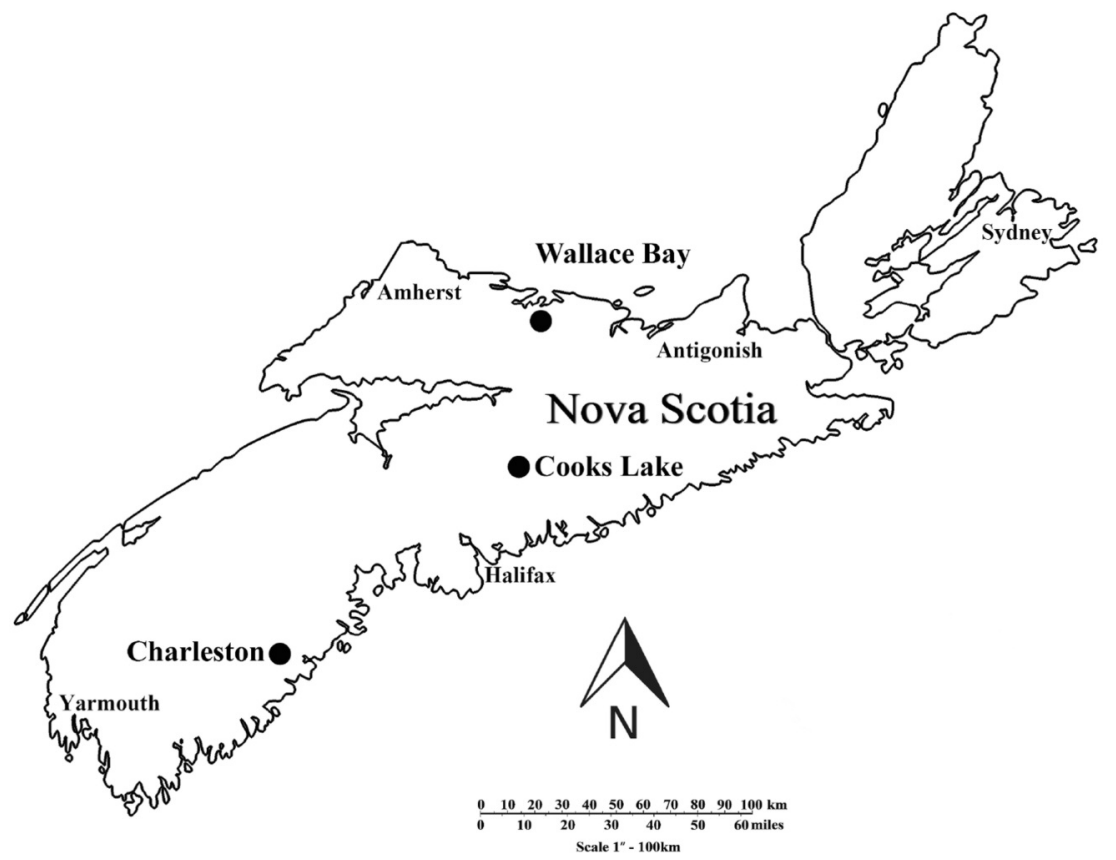

FIGURE 1. Location (black circles) of blue American Bullfrogs, Lithobates catesbeianus, in Nova Scotia. 
The first Nova Scotia record of a blue American Bullfrog is an adult female that was photographed on the Medway River at Charleston, Queens County (44ำ $\left.10^{\prime} 00^{\prime \prime} \mathrm{N}, 6^{\circ} 39^{\prime} 30^{\prime \prime} \mathrm{W}\right)$ by Chris Woodworth on 26 July 1980 (Figure 2). This record, accompanied by a painting of the frog by Fred W. Scott, was published by Gilhen (1984). The back and upper sides of this bullfrog were powder blue with blackish spotting and small greenish-yellow blotches, which were larger, more frequent, and more prominent posteriorly. Both eyes had a blueish-black pupil and the irises were yellowish green with blackish freckling. Both tympana were powder blue with some yellowish-green blotches. The back of the front legs was greenish brown while the colour of the hind legs was similar to that of the trunk.

The second blue bullfrog was an adult male, photographed at the edge of Cooks Lake, Halifax County, Nova Scotia, $45^{\circ} 00^{\prime} 20^{\prime \prime} \mathrm{N}, 63^{\circ} 15^{\prime} 00^{\prime \prime} \mathrm{W}$ by Darrell Abolit, on 15 June 2007 (Figure 3). From a distance, this individual appeared powder blue on the back. Observed at close range, it had a bluish cast on an otherwise normal green colour. The bluish-black spots were darker than the rest of the back and sides. The sides of the head appeared normal in colour.
The third blue bullfrog was an adult female that was first observed in a dug pond, at Route 6, Wallace Bay area, Cumberland County, Nova Scotia, 4548'50"N, 6333'30"W, by Maria Duynisveld, Grace Keats, and Emma Keats, on 4 August 2014 (Figure 4 and cover). This bullfrog was blueish with large black patches. The tympana were darker blue than the rest of the body.

In natural habitat and sunlight, these frogs appear powder blue in colour to the human observer, with some brownish-black spotting, and, in the case of the Wallace Bay individual, black patches. However, in captivity, the Wallace Bay bullfrog was observed to be a metallic greyish-green colour (Figure 5). These observed colour changes could be due to changes in the quality of ambient light, from natural sun to fluorescent laboratory illumination, or to physiological colour change involving pigment translocation within the DCU. Dispersion of melanin throughout melanophores can reduce light scattering by the iridophore layer and darken the skin, causing previously light blue frogs to appear much darker. The process of physiological colour change is under hormonal control, where low concentrations of melatonin activate the $\mathrm{Mel}_{1 \mathrm{c}}$ receptor, resulting in movement of melanin granules toward the centre of the cell, lightening skin colour (Sugden et al. 2004).

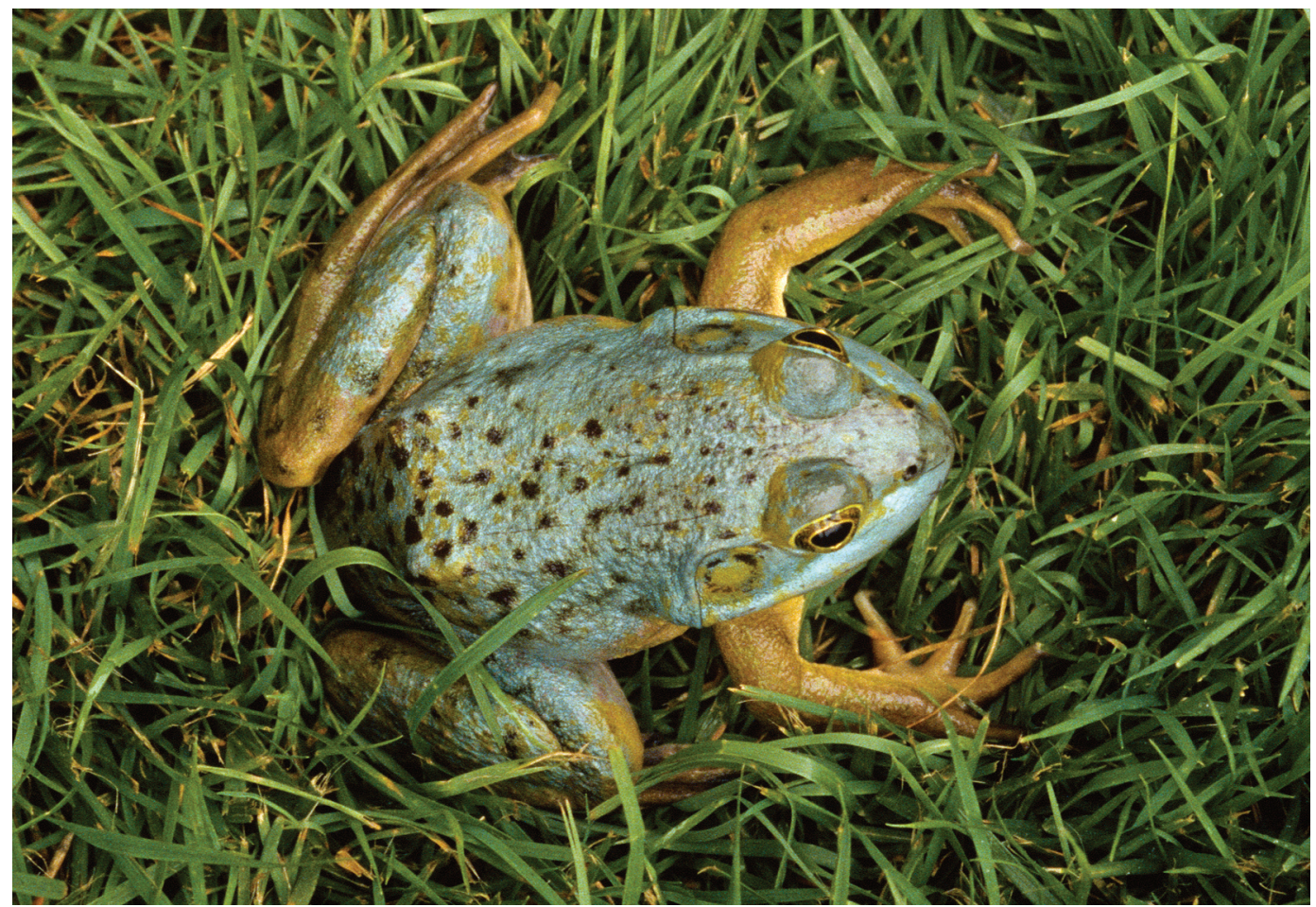

FIGURE 2. First record of a blue American Bullfrog, Lithobates catesbeianus, an adult female, photographed at Charleston on the Medway River, Queens County, Nova Scotia, 44¹0'00"N, 64³9'30"W, on 26 July 1980. Photo: Chris Woodworth. 


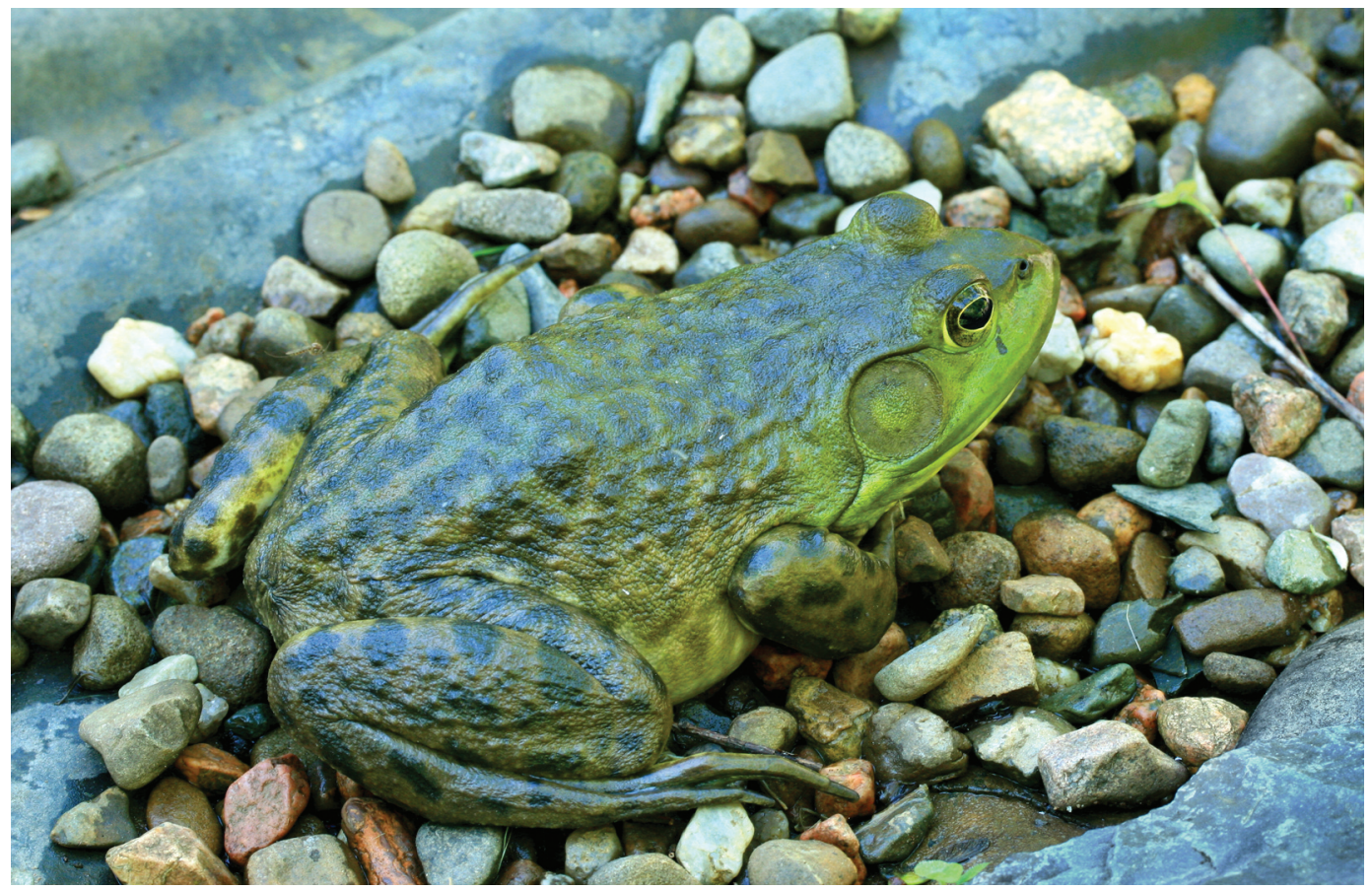

FIGURE 3. Second record of a blue American Bullfrog, Lithobates catesbeianus, an adult male, photographed at the edge of

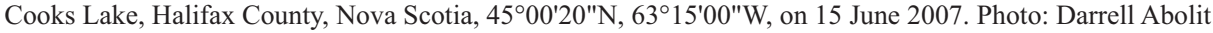

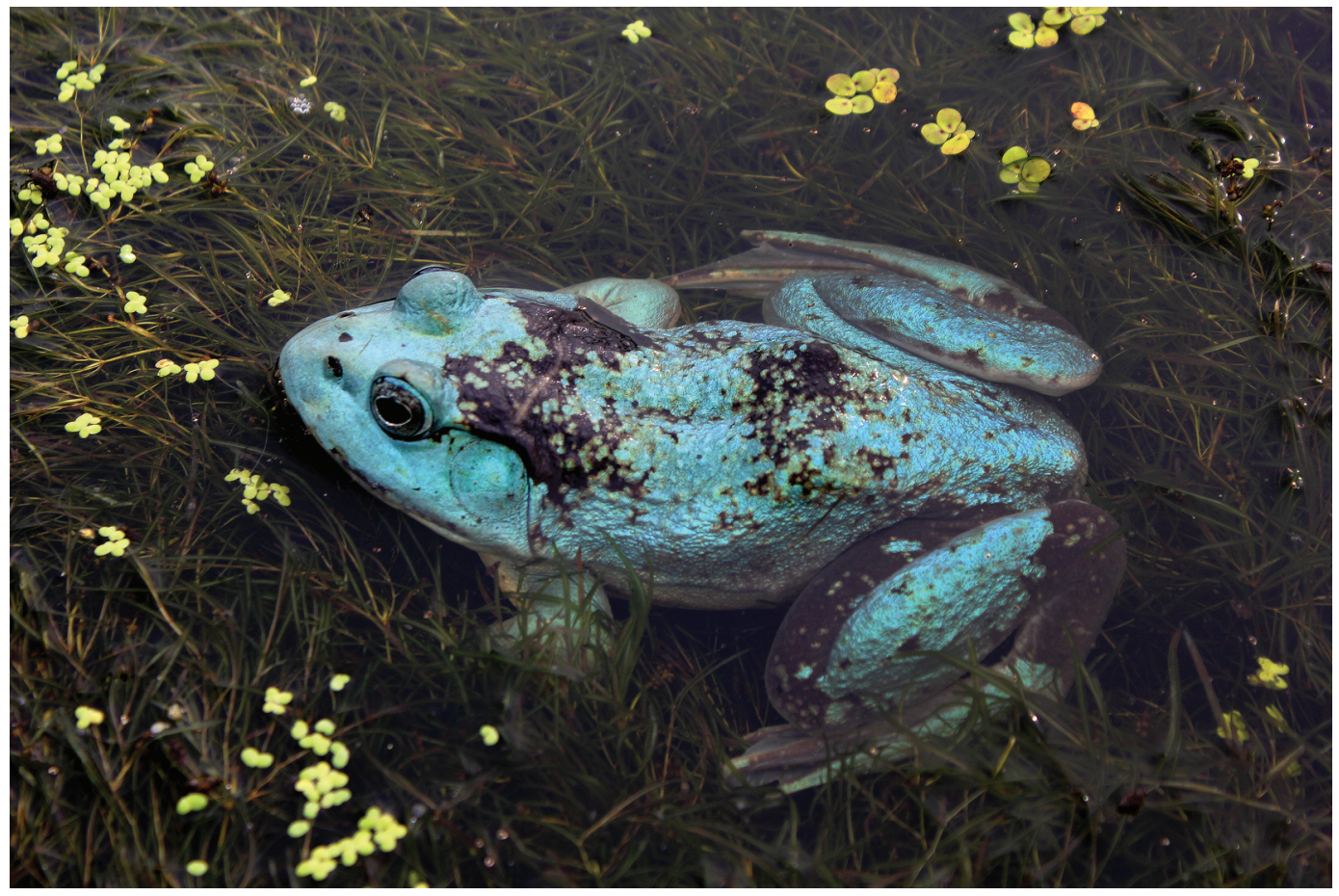

FIGURE 4. Third record of a blue American Bullfrog, Lithobates catesbeianus, an adult female, captured in dug pond, Route 6,

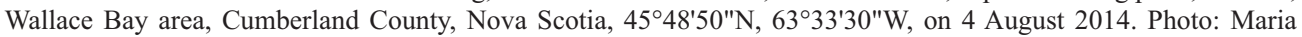
Duynisveld, Grace Keats, and Emma Keats. 


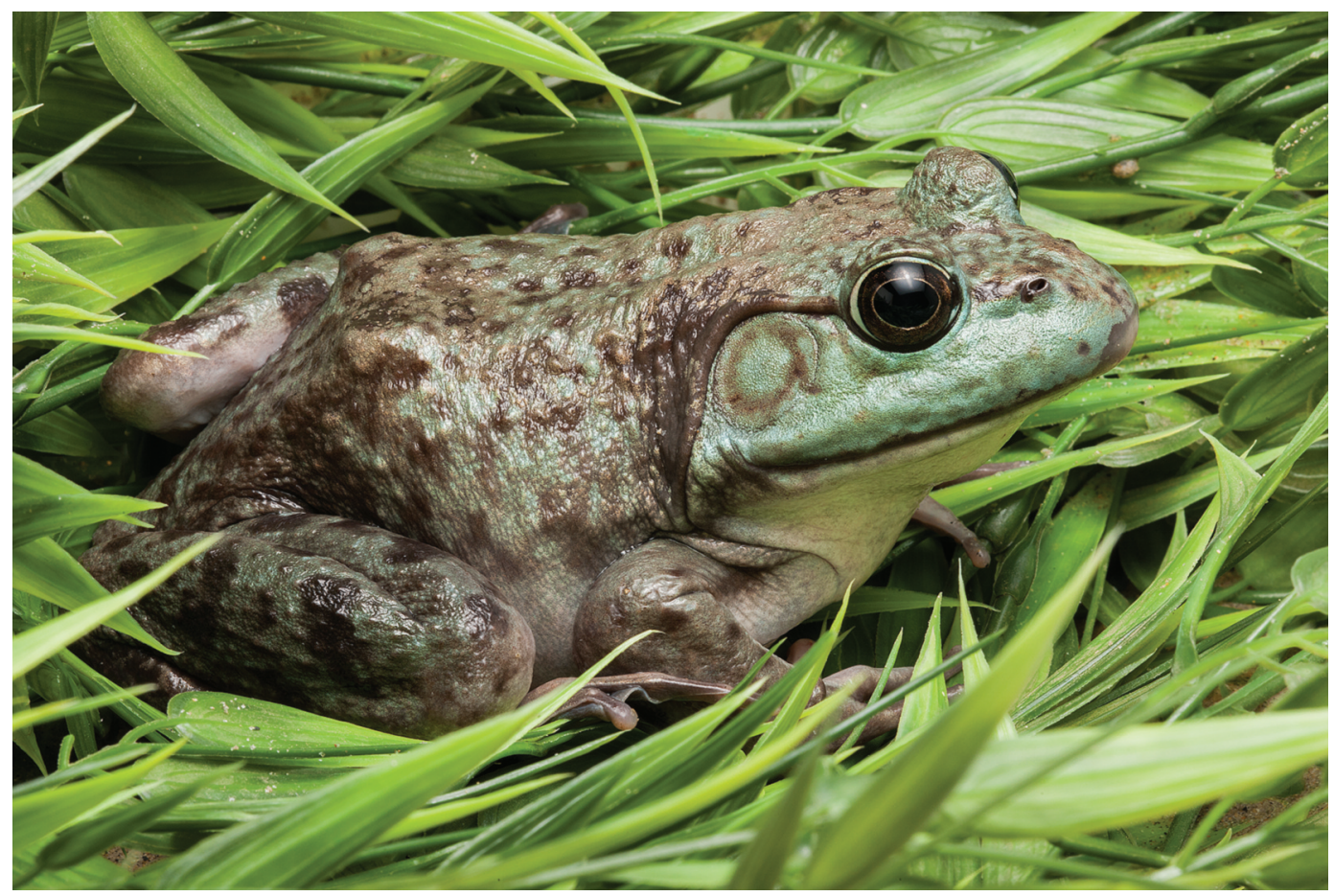

FIgURE 5. American Bullfrog from the Wallace Bay area, Nova Scotia, photographed in captivity under artificial light. The blue parts look metallic greyish green and the black blotches look brownish black. Figure 4 shows the same bullfrog photographed in sunlight. Photo: Roger Lloyd.

\section{Acknowledgements}

The authors thank Andrew Hebda who pre-reviewed the manuscript and naturalist Interpreters, Heather McKinnon-Bradshaw, Graham Caswell, Renee McKinistry, and Liz Spence, for their professional care of live American Bullfrogs displayed in the Nature Laboratory and Netukulimk Gallery, Nova Scotia Museum. Roger Lloyd, photographer, Nova Scotia Museum, developed digital images for Figures 2, 3, and 4, and original photography for Figure 5 and the cover.

\section{Literature Cited}

Bagnara, J. T., J. D. Taylor, and M. E. Hadley. 1968. The dermal chromatophore unit. Journal of Cell Biology 38: 67-79.

Bagnara J. T., S. K. Frost, and J. Matsumoto. 1978. On the development of pigment patterns in amphibians. American Zoologist 18: 301-312.
Bechtel, H.B. 1995. Reptile and Amphibian Variants: Colors, Patterns, and Scales. Kreiger Publishing, Malabar, Florida, USA.

Berns, M. W., and L. D. Uhler. 1966. Blue frogs of the genus Rana. Herpetologica 22(3): 181-183.

Dodd, C. K. 2013. Frogs of the United States and Canada, Volume 2. John Hopkins University Press, Baltimore, Maryland, USA.

Gilhen, J. 1984. Amphibians and Reptiles of Nova Scotia. Nova Scotia Museum, Halifax, Nova Scotia, Canada.

Jablonski, D., A. Alena, P. Vlček, and D. Jandzik. 2014. Axanthism in amphibians: a review and the first record in the widespread toad of the Bufotes viridis complex (Anura: Bufonidae). Belgian Journal of Zoology 144: 93-101.

Sugden, D., K. Davidson, K. A. Hough, and M. T. Teh. 2004. Melatonin, melatonin receptors and melanophores: a moving story. Pigment Cell Research 17: 454-460.

Yasutomi, M., and S. Yamada. 1998. Formation of the dermal chromatophore unit (DCU) in the tree frog Hyla arborea. Pigment Cell Research 11: 198-205.

Received 8 April 2015

Accepted 3 September 2015 